製剤使用基準，いわゆる standard surgical blood order を表 2 亿示した. 院内においては, 自己冷凍赤血球, 自 己冷涷血漿を初の沶の 5 単位, 血液センターでは, type and screen (T\&S) を行った濃厚赤血球を準備するとい う方法である。な扔，図 1 は現在当施設で使用されてい る体外循環装置である.

\section{考察}

MSBOS とは，準備した血液単位数を実際に輸血して 使用する単位数にできるだけ近づけることを目標とする あのであり, 具体的に $C / T$ 值が 1.5 以下を目安として 血液を準備するのであるが, 表 1 , 表 2 の結果より全体的 飞術前に適正な量の血液が準備されておらず，MSBOS の導入が意義あるあのと考えられた．輸血単位数の多い 開心術領域においても MSBOS の導入が，輸血製剂有 効利用の点から必要であると考えられた.
結 語

(1) 開心術における血液準備をより合理的なすのにす るために, 最近の開心術に扔ける術式別血液準備量 $(C)$ 之実際輸血量 $(T)$ より $C / T$ 值を算定し, 本院におけ る開心術の MSBOS を設定した。

(2) 本院に拈ける自己冷凍血液の利用状況汃ら自己冷 凍血液を主体とした standard surgical blood order を 設定し，以後血液センターへの血液返品率を著減させ た.

文 献 1) 当山真人ほか：胸部外科 34:669, 1981, 2) Toyama, M. et al. : Low Temp. Med. 15 : 21, 1989. 3) 隅田 幸男: 冷凍自家血液 (frozen autologous blood) 一充填人工心 肺による開心術一. 体外循環の最近の進歩. 石喬他編, pp. 53-58, 日本人工藏器学会, 東京, 1978, 4) 湯浅晋治: Medicina 26 : 608，1989. 5) 脇本信博: Curr. Ther. 7: 1023.

\title{
166 自己血によるフィブリン糊
}

\section{東京大学 胸部外科 \\ 近田正英幕 内晴朗松永仁古瀬彰}

現在，心臓血管外科領域に㧍いて，市販の同種血フィ ブリン糊が広く使用されている。しかし非 $\mathrm{A}$ 非B肝炎な ごの未知のウイルス感染の可能性を否定できず，価格も 高い、われわれは，自己血から得られたクリオプレシピ テートをフィブリン糊として使用し良好な結果を得たの で報告する。

\section{対象と方法}

自己クリオプレシピテートの作製法は，自己血 400 $\mathrm{ml}$ を採血し, 遠心分離して血漿と濃赤血飞分け, 得た 血漿を一 $80^{\circ} \mathrm{C}$ 泠涷保存しておく．ての自己 FFP を手 術 2 日前より $4{ }^{\circ} \mathrm{C}$ 保冷庫にて解凍し，4000 回転で 15 分間遠心して得られる沈殿物が，クリオプレシピテート である(図 1 )。自己クリオプレシピテートは，全血 400 $\mathrm{ml}$ から平均 $14 \pm 3.5 \mathrm{ml}(8 \sim 20 \mathrm{ml})$ 得られた.

使用に際して，自己クリオプレシピテートを $\mathrm{A}$ 液と し,トロンビン末 5000 単位, 0.5 モル塩化カルシウム液 $1 \mathrm{ml}$ およびアプロチニン 3500 単位を, 蒸留水 $7.5 \mathrm{ml}$ で溶解した液を B 液とし，A液とB液を交互に重層法
で，必要箇所へ塗布した(表 1 )。

対象は，男 19 例，女 7 例の計 26 例で，年齢は， 52.2 土15.4 歳 (14 72歳) であった。

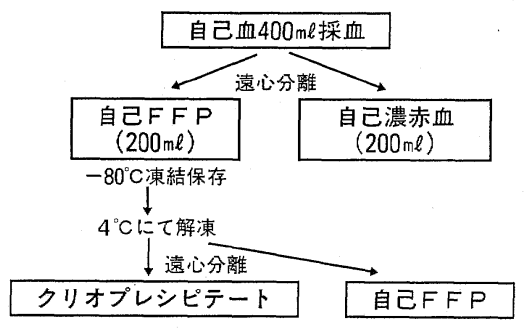

図 1 クリオプレシピテート作製法

表 1 使用 法

A液：クリオプレシピテート $14.0 \pm 3.5 \mathrm{ml}(8.0 \sim 20.0 \mathrm{ml})$

$B$ 液：トロンビン末 5000 単位 0.5 モル塩化カルシウム液 $1 \mathrm{ml}$ アプロチニン 3500 単位 蒸留水 $7.5 \mathrm{ml}$

$\mathrm{A}$ 液と B液を, 交互に重層法で必要䇢所へ塗布 
術式の内訳は, CABG 13 例, MVR 7 例, TAA およ びAAA に対する人工血管移植術各 1 例および AVR, TAP, Bentall 手術, 副伝導路切断術各 1 例であった。

手術時に自己フィブリン糊を使用し，その効果を調べ た.また 1989 年の症例で市販品 (ベリプラストP)を 使用した開心術 18 例と, 自己フィブリン糊を用いた開 心術 24 例の, 術後 12 時間の排液量を比較した。ささ にその成分を調べ，比較した。

\section{結果}

CABG ではグラフト吻合部へ，弁膜症手術では大動 脈や心房の縫合部へ用い，市販品よりやや良好な止血効 果が得られた. 胸部大動脈の手術時にアルブミンで preclotting したグラフトのサイズが合わず,急遽自己クリ オプレシピテートを外側より塗布した woven Dacron double velour のグラフトを用いたが血液の漏出はまっ たく認められなかった。

1989 年の症例で市販品を使用した開心術 18 例と, 自己フィブリン糊を用いた開心術 24 例の術後 12 時間 の排液量の比較では, 自己フィブリン糊使用群は, $545 \pm$ $429 \mathrm{ml}$, 市販品使用群は, $685 \pm 350 \mathrm{ml}$ で有意差はなか った。両者の体外循環時間は, 自己フィブリン糊使用群 $188 \pm 56$ 分, 市販品使用群 $210 \pm 92$ 分で有意差がなか った.

表 2 は，自己クリオプレシピテート 14 例と市販品 4 検体の成分分析の比較である，止血には，フィブリノー ゲンと第彺因子の量が重要である. 自己クリオプレシピ テートのフィブリノーゲン量は, $43.5 \pm 17.2 \mathrm{mg} / \mathrm{dl}$ で, 第XII因子の量は, 正常血漿の $10.6 \pm 2.5$ 倍であり,市販

表 2 成分分析

\begin{tabular}{|c|c|c|}
\hline \multicolumn{2}{|c|}{ 自己クリオプレシピテート } & 市販品 \\
\hline $\begin{array}{l}\text { Fibrinogen } \\
\text { 第埕因子 }\end{array}$ & $\begin{array}{l}43.5 \pm 17.2 \mathrm{mg} / \mathrm{ml} \\
10.6 \pm 2.5 \text { 倍 }\end{array}$ & $\begin{array}{l}75.5 \pm 7.7 \mathrm{mg} / \mathrm{ml} \\
57.3 \pm 5.8 \text { 倍 }\end{array}$ \\
\hline 第 II 因子 & $289 \pm 11 \%$ & $5 \%$ 未満 \\
\hline 第 V因子 & $52 \pm 4 \%$ & $5 \%$ 未満 \\
\hline 第VII因子 & $204 \pm 10 \%$ & $52 \pm 9 \%$ \\
\hline 第䜣因子 & $653 \pm 38 \%$ & $76 \pm 12 \%$ \\
\hline 第IX因子 & $310 \pm 21 \%$ & $5 \%$ 未満 \\
\hline 第X因子 & $186 \pm 10 \%$ & $46 \pm 13 \%$ \\
\hline 第XI因子 & $45 \pm 7 \%$ & $20 \pm 8 \%$ \\
\hline 第XII因子 & $36 \pm 17 \%$ & $5 \%$ 未満 \\
\hline
\end{tabular}

品よりやや低值であった，第II， III, IX, X因子は，正 常血漿の $2 \sim 3$ 倍, 第 $\mathrm{III}$ 因子は正常血墏の 6.5 倍を示 し，市販品より多く含まれていた．他の因子屯正常血漿 の $50 \%$ 前後之市販品より高值であった。

\section{考察}

心蔵血管外科領域では，人工心肺やへパリンを使用す るため, 術後の出血は重要な問題であり，対策として種 種の方法が試みられている. 1976 年に Sprangler ら が，初めて心臓血管外科領域でフィブリン糊を使用して

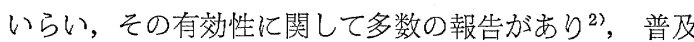
している。

しかし，今回われわれが使用した自己血によるフィブ リン糊の使用報告例は本邦では皆無であり，フィブリン 糊の販売が許可されていないアメリカにおいて，耳鼻科 や整形外科領域において散見されるのみである ${ }^{31}$. 自己 フィブリン糊は，最近広まりつつある自己血貯血の副産 物として，比較的簡単に作製することができる。そして 市販品と違って，非 $\mathrm{A}$ 非 $\mathrm{B}$ 肝炎など未知のウイルスの感 染の可能性がなく，経済的にも廉価で作製可能である。 フィブリノーゲン，第XII因子が，市販品之比べて低濃度 であったが，臨床的効果は，やや優れているように思わ れ，加熱処理を加えていないととや，他の凝固因子が多 く含まれているととが関与している可能性がある.

また，自己クリオプレシピテートは，全血 $400 \mathrm{ml}$ か ら $14 \mathrm{ml}$ 前後と多量に得られるのでグラフトを preclotting するのに有用であり単独の使用で，血液の漏出は まったく認められなかった，しかし，待期的手術ができ かつ自己血採血ができる症例に限られるという制約があ り, 救急手術には，詨応できない弱点がある.

\section{結 論}

1）自己血によるフィブリン糊は，市販品と比較し て，ほとんど変わらない止血效果が得られた。

2）非 $\mathrm{A}$ 非B肝炎などの未知のウイルス感染の危険が ないため有用であり，今後頻用すべき手段と思われる。

文 献 1) Sprangler, H.P.: Wien. Klin. Wochenschr. 88 (Suppl. 49) : 1, 1976. 2) 古田直樹ほか：新薬之臨床 $\mathbf{3 5}$ : 1955, 1986. 3) Dennis, F. et al.: Drug. Intell. Clin. Pharm. 22 : 946, 1988. 